5. Yefremova, T. F. (2000) Novyy slovar russkogo yazyka. Tolkovoslovoobrazovatelnyy. Moskva: Russkiy yazyk URL: http://gufo.me/dict/ efremova/master-klass. (data zvernennya: 10.09.2019). [in Russian].

6. Zhukov, I. M. (2007) Uroki zhizni (o G.G. Neygauze). Moskva: Muzykalnaya akademiya. №1. S. 39 - 45. [in Russian].

7. Krivtsun, O.A. (2000) Estetika: Uchebnik. Moskva: Aspekt Press. [in Russian].

8. Losev, A. F. 12 tezisov ob antichnoy kulture. URL: http://psylib. org.ua/books/_losew02.htm (data zvernennya: 17.11.2019). [in Russian].

9. Milshteyn, Ya. I. (1975) Konstantin Nikolaevich Igumnov. Moskva: Muzyka [in Russian].

10. Platon (1994) Sobranie sochineniy v 4 t. / Rossiyskaya akademiya nauk, institut filosofii. Moskva: Mysl. Tom 4. [in Russian].

11. Khaydegger, M. (1993) Vremya i bytie: Stati i vystupleniya. Moskva: Respublika. [in Russian].

12. Jerger, W. (2010) The Piano Master Classes of Franz Liszt, 1884 1886: Diary Notes of August Gцllerich. Bloomington: Indiana University Press [in English].

UDC $78.03+782.1 / 784.95$

DOI https://doi.org/10.31723/2524-0447-2019-29-2-15

Wang Na

ORCID: 0000-0001-6014-1604

Applicant at the Department of Music History and Musical Ethnography

Odessa National A. V. Nezhdanova Academy of Music

WangnaOd19@gmail.com

\title{
MODERN OPERA HOUSE AS A SUBJECT OF MUSICOLOGIST STUDIES: MUSICAL, HISTORICAL AND INTERPRETATION ASPECTS
}

The aim of the article is to identify the fundamental principles, artistic parameters and value-semantic guidelines of the modern opera house, considered in a wide musicological discursive field. To study the socio-aesthetic role of artistic value, theoretical parameters for considering the relationship and mutual influence of the phenomena of theater and opera are formed. The methodology of the work is determined by a system of historical and theoretical approaches, each of which is represented by a complex of methods based on the combination of such methodological approaches as musical and historical, interpretive, opera

(C) Wang Na, 2019 
study, theater studies, textological and semiological. The scientific novelty is in the substantiation and systematization of approaches to the study of the phenomenon of modern opera house, within the framework of which the repertoire factography of modern European and Chinese opera houses is created. New interpretative possibilities and directorial decisions are revealed, due to the expansion of artistic and creative boundaries of the opera house as one of the leading sociocommunicative mechanisms of the modern musical and cultural space.

Conclusions. Based on this, we can conclude that the modern opera house, as a phenomenon derived from musical theater, basically contains reliance on the relatedness of the musical and theatrical components of the action, since in this type of theater they are an indissoluble unity; direct connection with the historical past, with the cultural and historical traditions that nourished it, together with possible cultural influences from outside; the concentration of theatrical action around the protagonist with an in-depth description of his inner world, psycho-emotional states around which the main event outline of the composition unfolds. The opera house occupies an important place in the musical and historical process and acquires the significance of one of the most powerful socio-cultural institutional mechanisms of culture, exerting a significant impact on the formation of the value-semantic dominants of culture and the personal consciousness of a person.

Key words: modern opera house, musical theater, opera hero, artistic image, opera character.

Ван На, здобувач кафедри історії музики та музичної етнографії Одеської національної музичної академії імені А. В. Нежданової

Сучасний оперний театр як предмет музикознавчого вивчення: музично-історичний та інтерпретаційний аспекти

Метою статті є виявлення основоположних принципів, художніх параметрів і ціннісно-смислових орієнтирів сучасного оперного театру, що розглядаються в широкому музикознавчому дискурсивному полі. Для вивчення соціально-естетичної ролі художнього значення формуються теоретичні параметри розгляду взаємозв'язку й взаємовпливу феноменів театру й опери. Методологія роботи визначається системою історичного й теоретичного підходів, кожен з яких представлений комплексом методів, заснованих на об'єднанні таких, як музично-історичний, інтерпретаційний, оперознавчий, театрознавчий, текстологічний $i$ семіологічний. Наукова новизна полягає в обгрунтуванні й систематизаціі підходів до вивчення явища сучасного оперного театру, в рамках яких створюється репертуарна фактографія сучасних європейських $i$ китайських оперних театрів. Виявляються нові інтерпретаційні можливості й режисерські рішення, зумовлені розширенням художньо-творчих кордонів оперного театру як одного з провідних соціокомунікативних механізмів сучасного музично-культурного простору.

Висновки. Сучасний оперний театр як феномен, похідний від музичного театру, в основі свойй містить опору на спорідненість музичного й театрального компонентів діі, оскільки в такому вигляді театру вони $\epsilon$ нерозривною єдністю; безпосереднім зв'язком з історичним минулим, 
з його культурно-історичними традиціями в сукупності з можливими культурними впливами ззовні; зосередженістю театральної дії навколо головної дійової особи з поглибленою характеристикою ї̈ внутрішнього світу, психоемоційних станів, навколо яких і розгортається головна подієва канва твору. Оперний театр займає важливе місце в музично-історичному процесі й набуває значення одного з найпотужніших соціокультурних інституційних механізмів культури, роблячи істотний вплив на формування ціннісно-смислових домінант культури й особистісну свідомість людини.

Ключові слова: сучасний оперний театр, музичний театр, оперний герой, художній образ, оперний персонаж.

Ван На, соискатель кафедры истории музыки и музыкальной этнографии Одесской национальной музыкальной академии имени А. В. Неждановой

Современный оперный театр как предмет музыковедческого изучения: музыкально-исторический и интерпретационный аспекты

Целью статьи является исследование основополагающих принципов, художественных параметров и иенностно-смысловых ориентиров современного оперного театра, рассматриваемые в широком музыковедческом дискурсивном поле. Для изучения социально-эстетической роли художественного значения формируются теоретические параметры рассмотрения взаимосвязи и взаимовлияния феноменов театра и оперы. Методология работы определяется системой исторического и теоретического подходов, каждый из которых представлен комплексом методов, основанных на объединении таких, как музыкально-исторический, интерпретационный, опероведческий, театроведческий, текстологический и семиологический. Научная новизна заключается в обосновании и систематизации подходов к изучению явления современного оперного театра, в рамках которых создается репертуарная фактография современных европейских и китайских оперных театров. Выявляются новые интерпретационные возможности и режиссерские решения, обусловленные расширением художественно-творческих грании оперного театра как одного из ведущих социокоммуникативных механизмов современного музыкально-культурного пространства.

Выводы. Современный оперный театр как производный от музыкального театра феномен в основе своей содержит опору на целостность музыкального и театрального компонентов действия, поскольку в таком виде театра они представляют собой нерасторжимое единство; непосредственную связь с историческим прошлым, с питавшими его культурно-историческими традициями в совокупности с возможными культурными влияниями извне; сосредоточенность театрального действия вокруг главного действующего героя с углубленной характеристикой его внутреннего мира, психоэмоциональных состояний, вокруг которых и разворачивается главная событийная канва произведения. Оперный театр занимает важное место в музыкально-историческом процессе и приобретает значение одного из мощнейших социокультурных институииональных механизмов культуры, оказывая существенное 
воздействие на формирование иенностно-смысловых доминант культуры и личностное сознание человека.

Ключевые слова: современный оперный театр, музыкальный театр, оперный герой, художественный образ, оперный персонаж.

Relevance of the article. Among the most popular areas of modern musical and cultural life, one of the leading positions is occupied by the opera house, the influence and authority of which has significantly increased in recent decades.

Today, the opera house is becoming a place where the compositions of the great masters of the distant past return from oblivion, an example of which is the numerous performances of opera compositions of the Baroque era, both singular and within the framework of various opera festivals. Along with this, premieres of new works by contemporary composers take place on opera stages, as well as staging of opera masterpieces in a new director's reading, using the latest innovative techniques of modern director's theater, which reveals the special artistic and communicative functions of the opera house.

The new conceptual unity of opera and theater practice is evidenced by the strengthening of dialogical interaction between various national historical opera schools, primarily from their institutional, primordially theatrical side, which allows to speak of the existence of a single world opera house at the beginning of the XXI century. This phenomenon includes not only various European national opera and theater systems, but also various theatrical systems of China, America, Japan, etc., many of which relatively recently entered into a close dialogue with the European opera and theater tradition, developing up to this point in accordance with their national and cultural attitudes.

At the same time, it should be noted the importance of the traditions of European opera, which to this day is the most important component of the repertoire of all world opera houses and the foundation for the further development of the world opera house. Therefore, the fundamental properties, the main essential indicators of opera creativity are first of all formed better, deeper of all, they reveal themselves when referring to the repertoire artifacts of European opera, in their obligatory connection with the socio-cultural functions of the theater.

It is necessary to emphasize the importance of developing theoretical criteria for assessing the artistic-activity relationship of theatrical creative practice and the genre form of opera, as well as 
determining the entire range of textological interpretative conditions important to study the current state of this relationship and the main components, factors in the development of modern opera house.

The aim of the article is to identify the fundamental principles, artistic parameters and value-semantic guidelines of the modern opera house, considered in a wide musicological discursive field. To study the socio-aesthetic role of artistic value, theoretical parameters for considering the relationship and mutual influence of the phenomena of theater and opera are formed. The methodology of the work is determined by a system of historical and theoretical approaches, each of which is represented by a complex of methods based on the combination of such methodological approaches as musical and historical, interpretive, opera study, theater studies, textological and semiological. The scientific novelty is in the substantiation and systematization of approaches to the study of the phenomenon of modern opera house, within the framework of which the repertoire factography of modern European and Chinese opera houses is created. New interpretative possibilities and directorial decisions are revealed, due to the expansion of artistic and creative boundaries of the opera house as one of the leading socio-communicative mechanisms of the modern musical and cultural space.

Presenting the main material. The study of modern opera house and opera creativity presupposes, on the one hand, an appeal to specific composer poetics, since opera creativity always depends on the manifestation of a personal factor, as it is author's. On the other hand, it leads to the discovery of temporal characteristics both of a general historical nature and in connection with the time of creation of individual opera compositions and the periodization of the composition of opera authors. In addition, the focus is on the interpretative characteristics of the studied opera composition, as well as the theatrical and staging side of the opera house as a whole. Among the musicological compositions devoted to the study of the phenomenon of opera in all its guises and manifestations, works affecting the staging aspect of the functioning of this phenomenon are clearly insufficient. The work of M. CherkashynaGubarenko "Opera House in the Space of a Changing World" [4], in which the author offers a deep analysis of the repertoire of the largest opera houses of our time, which forms a kind of anthology of modern opera as an artistic phenomenon, is a rare example of this type of research. 
On the pages of her book M. Cherkashyna-Gubarenko builds an extended series of names, many of which, from the point of view of linear historical time, can hardly be called modern. Among the objects of the scientist's consideration, we can find the study of productions on the best opera stages of compositions by Monteverdi, Gluck, Beethoven, Verdi, Puccini, Leoncovallo, Massenet, Wagner, Tchaikovsky, Janacek, R. Strauss, Debussy, S. Prokofiev, Britten, Gubarenko and many others. The creativity of the composers, separated in historical time and space, turns out to be close and related to the artistic chronotopes of the modern opera house, if by the latter we mean the last third of the XX - beginning of the XXI century.

The very definition of "modern opera house" testifies to the existence of a special artistic, aesthetic and value-semantic phenomenon, which is directly related to the dominant cultural, historical and symbolic parameters of the culture in the depths of which the phenomenon under study originated. Thus, the modern opera house is, first of all, very closely related to the national cultural and historical tradition that gave birth to it, which is of particular importance in the study of cultural influences and dialogical interactions between types of cultures that are distant in aesthetic parameters, which include the interaction between European and Chinese opera traditions.

European opera art becomes a subject of deep interest on the part of Chinese cultural figures by historical standards quite late, namely on the verge of the XIX and XX centuries. Many researchers associate a similar interest in socio-political changes in China itself, which could not but affect cultural processes. It should be noted that, as Zhang Lizhen points out, "acquaintance with European musical culture for China passed mainly through Japan, which made certain adjustments" [5, p. 24].

The initiators of such a cultural dialogue were prominent musical and cultural figures who sought to establish creative contacts with representatives of European musical culture, which led to the acquaintance of residents of large Chinese cities with European opera masterpieces. So, in the first third of the XX century, the Italian opera troupe repeatedly toured Shanghai, which introduced Chinese listeners to such outstanding opera compositions as Aida, La Traviata, Rigoletto by G. Verdi, Cio-cio-san by G. Puccini, "Carmen" by J. Bizet and others. It should be noted that these opera compositions still occupy a very significant place on the 
opera stage in China, having a significant impact on the development of its opera house today.

Consequently, the phenomenon of the modern opera house is addressed to those value-semantic orientations and realities of generalized human experience, which have acquired the status of cultural and historical universals, and hence a meta-temporal purpose. The category "opera house" itself contains a certain duality, since, on the one hand, it is directed towards the phenomenon of theatricalization - dramatic theater, on the other - towards musical art, to the extent and linguistic expression in which it is represented by the genre form of opera. It should be noted that the opera house develops its own system of semantically significant emblems and symbols, according to which its own system of relationships between the hero and the surrounding reality is built. The function of these semantic signs, along with those indicated above, was also performed by stable, repetitive melodic and rhythmic formulas, keys, timbres, etc.

Proceeding from this, it becomes obvious that the conceptual definition of "modern opera house" indicates the existing division and comparison, both in theoretical and in analytical and textological terms, theatricality as a value-semantic paradigm of artistic culture; operality as a key feature of an artistic image (expression, speaking out) in its specific genre synthetic form; musicality as a conceptual property of opera interpretation.

Diverse musical and theatrical systems that arise in various national musical and cultural varieties and musical theater in its general constitutive quality is a special phenomenon of world culture, which has absorbed, reflected in an artistic form, the long historical experience of the human community, uniting and representing the specific features of various ethnic cultures.

When considering a modern opera house, it should be noted that, on the one hand, it is a product of the cultural and historical process, on the other, it relies on the musical and theatrical traditions existing in a particular culture, which are often associated with a complex of traditional folklore, religious-sacred, socio-cultural attitudes. Studying the path of the historical development of the modern opera house, its distinction in the chronotopic flow and the completeness of the action presented on the stage should be defined as one of the fundamental characteristics. This was already pointed out by Aristotle in Poetics, when he said that "tragedy is an imitation of an important and complete action, which has [a certain] volume, [produced] by speech, sweetened in different 
ways in its various parts, [produced] in action, and not in the narrative and accomplishing by means of compassion and fear the purification of such passions" [1, p. 651]. Therefore, Aristotle believed that the main task of the theater should be the desire to present an action that is significant in its artistic and substantive parameters, and, at the same time, presenting the action as a kind of complete sequence of events, which makes a theatrical performance akin to reality reproduced by artistic means.

In musical theater as a cultural and historical phenomenon and a product of the culture that formed it, attention should be paid to several important components, which largely explain the features and internal logic of the functioning of this phenomenon. The first component is the deep connection between the theatrical and musical levels of musical theater, due to the commonality of their artistic and aesthetic attitudes and the initial relatedness of these two levels, which can be characterized as the idea of historical unity, historical community, as an expression of the historical life of people in the theatrical art.

The second component is related to the characterization and interpretation of the image of a person who becomes the main character, the main hero of culture. In European theater, a person as a cultural hero throughout the history of musical theater found himself in different positions - from a certain opposition of religious interpretation in the Middle Ages, to its closeness to the divine principle in the ancient Greek and Renaissance theater, marked by signs of an anthropocentric worldview that strengthens interest in human life activity and to its personal uniqueness. In Chinese and Japanese theaters, the protagonists of a theatrical performance were often characters endowed with magical powers, carriers of the transcendental principle, and then a person literally reincarnated into his character, becoming a guide or mediator that allows the voice of a deity to sound.

The performer in the musical and theatrical production of China acts strictly within the framework of the canon formed throughout the evolution of the Chinese theater. That means, for him the main task is not the interpretation and playful recreation of his character, but the exact reproduction of all canonical attitudes associated with his character, accurate reproduction the existing performing form. As Zhang Lizhen rightly points out in his work devoted to the study of modern Chinese opera, "Chinese musical theater is the art of form brought to perfection, modern opera is the art of 
interpretation" [5, p. 93]. However, both for the European and for the oriental musical theater, and later for the opera house formed on its basis, the most important component is the musical expression of the profound psychological characteristics of the characters, which make it possible to express the main aspirations of the hero, his inner world and ideological attitudes.

Despite the genetic affinity of the opera house with the dramatic theater in terms of a number of internal structural and artistic and semantic parameters, the entire history of the origin and their further genesis demonstrates the desire of these artistic phenomena to gain some autonomy from the dramatic theater. This confrontation leads to the emergence of many intermediate (between dramatic and musical) theatrical forms, with different preponderance, with a complete or partial victory of the verbal or musical principle. But it also leads to the emergence of a number of synthetic musical and dramatic forms, including those that go beyond the boundaries of theatrical art itself, lead to the development of other visual-artistic, entertainment spheres of culture (film, television, musicals and show programs, advertising project, mass media, etc.) [2]. The parameters of the artistic unity and genetic integrity of musical theater can be found using the historiographic approach, that is, through retrospection, since in its successive development one form replaces another, significantly differing from the previous one and striving for an original interpretation of the components of the musical and theatrical genre.

But in this general history of the theater, one thing remains undeniable: the dialogical interaction of two forms of artistic convention - the verbal, which reveals the content of the action, solidary with its objective side, and the musical, which explains the meaning of this action and its objective realities, that is, indicating their meaning for a person, therefore, on the genuine deep motives of creating theatrical convention.

The illusion of life, which is becoming more important and effective, brighter and more attractive than life itself - this is the main paradox of theatrical art, which makes its musical forms a necessary part of the existence of culture in its two main tendencies - both human culture, in a person, and communication culture, human in culture.

Conclusions. Based on this, we can conclude that the modern opera house, as a phenomenon derived from musical theater, basically contains reliance on the relatedness of the musical and 
theatrical components of the action, since in this type of theater they are an indissoluble unity; direct connection with the historical past, with the cultural and historical traditions that nourished it, together with possible cultural influences from outside; the concentration of theatrical action around the protagonist with an in-depth description of his inner world, psycho-emotional states around which the main event outline of the composition unfolds.

The opera house occupies an important place in the musical and historical process and acquires the significance of one of the most powerful socio-cultural institutional mechanisms of culture, exerting a significant impact on the formation of the value-semantic dominants of culture and the personal consciousness of a person. The indicative side of the opera house from the moment of its inception to the present day is its orientation and appeal to the audience, the problem of demand, which turns out to be closely related to the repertoire of theaters, with the choice of compositions that meet the needs of our time. Today, in the age of the development of high-tech media communications, we can talk about the emergence of a "global audience", in which new information and communication opportunities and tools that arise as a product of the activities of globalized networks acquire a decisive importance. This situation makes it possible to create new quantitative and qualitative criteria for assessing the artistic phenomenon under consideration, which, in turn, changes the internal gradations, and sometimes makes the boundaries between the mass and the elite in modern culture permeable. The value-based aesthetic transformation of the audience includes increased attention to opera art, in particular, to the discussion of its socio-psychological significance, the specifics of its traditions, both artistic and socio-functional [3, p. 167].

All authors acknowledge the fact that opera has grown in popularity in the world over the past few decades, as well as the tendency of the return of public interest in classical forms of opera. This trend is interpreted by culturologists as evidence of the restructuring of the value hierarchy of modern culture, which interacts with the formation of a person's need for cultural self-identification, for the preservation and development of spiritual life.

Consequently, from the sociocultural side, the activities of a modern opera house are closely connected with the moral toposes of society, with the direction in which the educational life of society is carried out, as well as with interethnic interactions, 
positions and experience of relations of this society, which is especially important for the preparation of performing opera frames.

\section{BIBLIOGRAPHY}

1. Аристотель. Поэтика. Аристотель. Труды : в 4 т. Москва : Мысль, 1983. Т. 4. С. 645-680.

2. Лисенкова А. Социальная коммуникация как фактор развития музыкальной театральной культуры : дисс. ... канд. культурологии : 24.00.01. Санкт-Петербург, 2003. 213 с.

3. Лосева-Демидова Е. Оперное искусство как фактор формирования ценностных ориентаций зрительской аудитории : дисс. ... канд. социол. наук : 22.00.06. Москва, 2010. 179 с.

4. Черкашина-Губаренко M. Оперный театр в пространстве меняющегося мира: страницы оперной истории в картинках и лицах : монография. Киев, 2013. 468 с.

5. Чжан Личжэнь. Современная китайская опера: история и перспективы развития : дисс. ... канд. искусствоведения : 17.00.02. Санкт-Петербург, 2010. 149 с.

\section{REFERENCES}

1. Aristotle (1983). Poetika [Poetics]. Aristotle. Works (in 4 volumes). Moscow: Mysl', vol. 4, pp. 645-680 [in Russian].

2. Lisenkova, A. (2003). Sotsial'naya kommunikatsiya kak faktor razvitiya muzykal'noy teatral'noy kul'tury [Social communication as a factor in the development of musical theater culture]. Candidate's thesis. Saint-Petersburg [in Russian].

3. Loseva-Demidova, E. (2010). Opernoe iskusstvo kak faktor formirovaniya tsennostnykh orientatsiy zritel'skoy auditorii [Opera art as a factor in the formation of value orientations of the audience]. Candidate's thesis. Moscow [in Russian].

4. Cherkashyna-Gubarenko, M. (2013). Opernyy teatr v prostranstve menyayushchegosya mira: stranitsy opernoy istorii v kartinkakh i litsakh: monografiya [Opera house in the space of a changing world: pages of opera history in pictures and faces: monograph]. Kyiv [in Russian].

5. Zhang Lizhen (2010). Sovremennaya kitayskaya opera: istoriya i perspektivy razvitiya [Contemporary Chinese Opera: History and Development Prospects]. Candidate's thesis. Saint-Petersburg [in Russian]. 